Bangladesh J. Plant Taxon. 27(2): 391-405, 2020 (December)

(C) 2020 Bangladesh Association of Plant Taxonomists

\title{
ANGIOSPERMS IN NARSINGDI DISTRICT OF BANGLADESH: CLASS LILIOPSIDA
}

\author{
Robayda Khanam and Saleh Ahammad Khan \\ Plant Systematics and Biodiversity Laboratory, Department of Botany, \\ Jahangirnagar University, Savar, Dhaka, Bangladesh
}

Keywords: Angiosperms; Liliopsida; Narsingdi; Bangladesh.

\begin{abstract}
This study provides the taxonomic data on 168 plant species belonging to 96 genera and 23 families of Liliopsida (monocotyledons) extant in Narsingdi district of Bangladesh. These species are mostly comprised of herbs $(90.48 \%)$, followed by trees and shrubs (4.76\% each). Poaceae with 66 species under 37 genera is the best represented family, followed by Cyperaceae with 26 species of seven genera, Araceae with 16 species of 11 genera, Commelinaceae with 11 species of four genera and Arecaceae with 10 species of eight genera. Cyperus with 13 species appears as the largest genus, which is followed by Panicum with nine species, Digitaria with six species, and Commelina and Dioscorea with five species each. The six upazilas of this district are $39.77 \%$ similar in the species composition of their Liliopsida, but the similarity between the pairs of upazilas varies from $6.45 \%$ to $32.31 \%$. Roadside and fallow land habitats share the highest similarity (36.84\%) in species composition. Total 117 species are distinguished as economically useful. This study suggests for implementation of necessary measures in order to minimize the major threats to this plant group and to favor its sustainable development in the study area.
\end{abstract}

\section{Introduction}

Narsingdi district, situated in central Bangladesh, is a densely populated industrial area. The plant genetic-, species- and ecosystem diversities of this area might have a tremendous influence on the environment of this region. Nevertheless, the floristic elements and natural vegetation are rapidly decreasing in this district. Most of the areas of this district harboring its flora and plant diversity are being replaced by urbanization with numerous infrastructures, industrialization, habitat fragmentation, agricultural expansion and other human interventions. Considering the current trend of destruction and fragmentation of natural habitats, many plant species might disappear from this area before they are recorded and described.

After Hooker (1872-1897) and Prain (1903), some floristic studies covered the area of the present political boundary of Bangladesh including this district (Siddiqui et al., 2007 and Ahmed et al., 2008). Many other studies were conducted in different areas of this country (Rahman and Hassan, 1995; Islam et al., 2009; Arefin et al., 2011; Rahman et al., 2012; Rahman, 2013; Sarker et al., 2013; Rahman et al., 2015; Haque et al., 2018; Shetu et al., 2018). However, the flora or plant diversity of this district has never been studied before based on detail field inventories and examination of plant specimens, except the checklist of its 468 species of Magnoliopsida (Dicotyledons) recently published by Khanam et al. (2020). Thus, the Liliopsida and other plant groups of this area are left yet unexplored. Therefore, this study was conducted to fetch the basic taxonomic data on Liliopsida species extant in Narsingdi district, to know their current specific distribution and economic importance, to collect and preserve their representative specimens for future reference, and to identify the existing threats to their species diversity.

*Corresponding author, E-mail: robaydakhanam@yahoo.com 


\section{Materials and Methods}

Narsingdi district, located in between $23^{\circ} 46^{\prime} \mathrm{N}$ and $24^{\circ} 14^{\prime} \mathrm{N}$ and $90^{\circ} 35^{\prime} \mathrm{E}$ and $90^{\circ} 60^{\prime} \mathrm{E}$ (http://www.narsingdi.gov.bd), is comprised of an area of 1140.76 sq. km (BBS, 2011). The area is administered under six upazilas, namely Belabo, Monohardi, Narsingdi Sadar, Palash, Raipura, and Shibpur. It is composed of mostly plain lands including numerous agricultural fields, many industries, a huge fallow lands, many low and wet lands, some small hills, and densely populated homestead areas. This area includes a total of 89045 hectares of cultivable land and 22154 hectares of fallow land. In this area, the maximum and minimum annual average temperature are $36^{\circ} \mathrm{C}$ and $12.7^{\circ} \mathrm{C}$, respectively, and the annual rainfall is $2376 \mathrm{~mm}$ (BBS, 2011). The main rivers crossing this district are Meghna, Arial Khan, Haridhoa, Kalagachhia and Paharia.

This study was based on field data accumulated by thorough taxonomic inventories comprised of 32 field trips conducted in different seasons of 2014-2019 throughout the study area and laboratory data collected through the examination of representative specimens of each plant taxon. The collection, processing, drying and preservation of plant specimens were done following standard herbarium methods and techniques (Bridson and Forman, 1989; Singh and Subramaniam, 2008). All plant specimens of Liliopsida collected from the study area were examined at Plant Systematics and Biodiversity Laboratory of Jahangirnagar University and Bangladesh National Herbarium (DACB). The specimens were identified by consulting taxonomic descriptions and keys available in the relevant literatures (Hooker, 1872-1897; Prain, 1903; Nasir and Ali, 19802005; Wu and Raven, 2000; Wu et al., 2006-2010), and by matching with the respective voucher specimens of DACB and Jahangirnagar University Herbarium (JUH). Additionally, the relevant specimen images including those of types available in the web pages of different international herbaria, especially of Royal Botanic Gardens Kew (K), and the Conservatoire et Jardin botaniques de la Ville de Genève (G), and pertinent illustration of Flora of China (Wu and Raven, 2000; Wu et al., 2006-2010) were matched. The voucher specimens of all taxa studied are preserved at JUH.

Recent literatures (Wu and Raven, 2000; Wu et al., 2006-2010; Zuloaga et al., 2008; Jørgensen et el. 2014; Schatz et al., 2020) and nomenclatural databases (The Plant List, 2013; TROPICOS, 2017; IPNI, 2018; Madagascar Catalogue, 2020) were consulted for nomenclatural verification. The common names were collected from Huq (1986), Siddiqui et al. (2007), Ahmed et al. (2008) and through interviews with local people during field visits. In the checklist, the families are arranged following Cronquist (1981), and all genera and species alphabetically (Table 1). However, in case of the Liliaceae taxa, their new combination under three separate families, viz. Hypoxidaceae, Amarylidaceae and Asparagaceae, and the recent circumscription of Aloaceae under Asphodelaceae, accepted by APG IV System (Angiosperm Phylogeny Group, 2016), are followed. The economic uses of the species were recognized consulting the relevant literatures (Ghani, 1998; Van Valkenburg and Bunyapraphatsara, 2002; Siddiqui et al., 2007; and Ahmed et al., 2008) and through interviews with the local people during the field visits. The similarities in the upazilas of the study area and habitats in species composition were measured by Jaccard coefficient (Jaccard, 1912).

\section{Results and Discussion}

This study confirmed the current occurrence of total 168 species of monocotyledons (Liliopsida) under 96 genera and 23 families in Narsingdi district. All of these species are presented here in the checklist with habit, habitat, distribution within the study area, and representative specimen examined (Table 1). Among the monocot families documented by this study, only five were represented by more than $10(10-66)$ species each and 10 by single species 


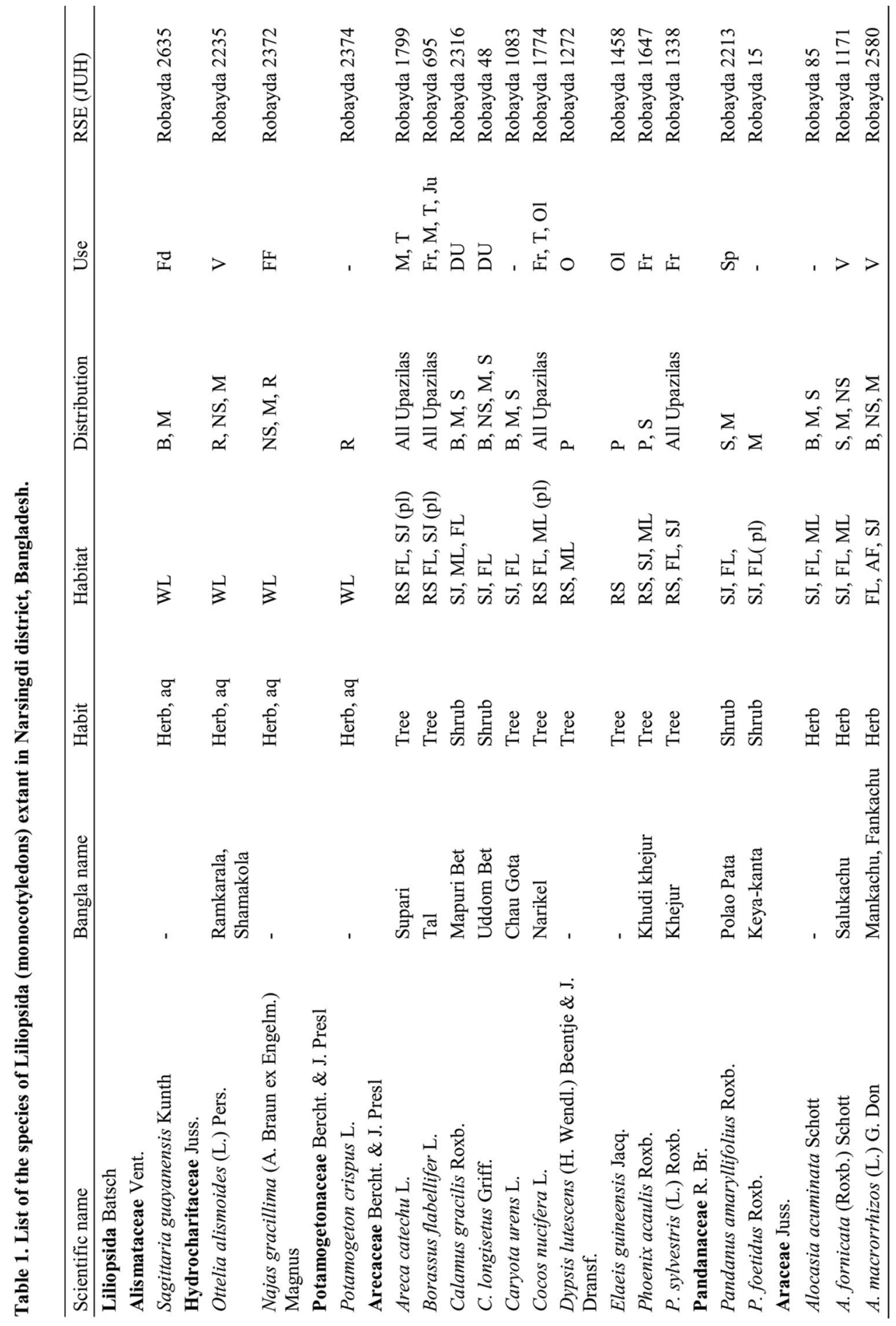




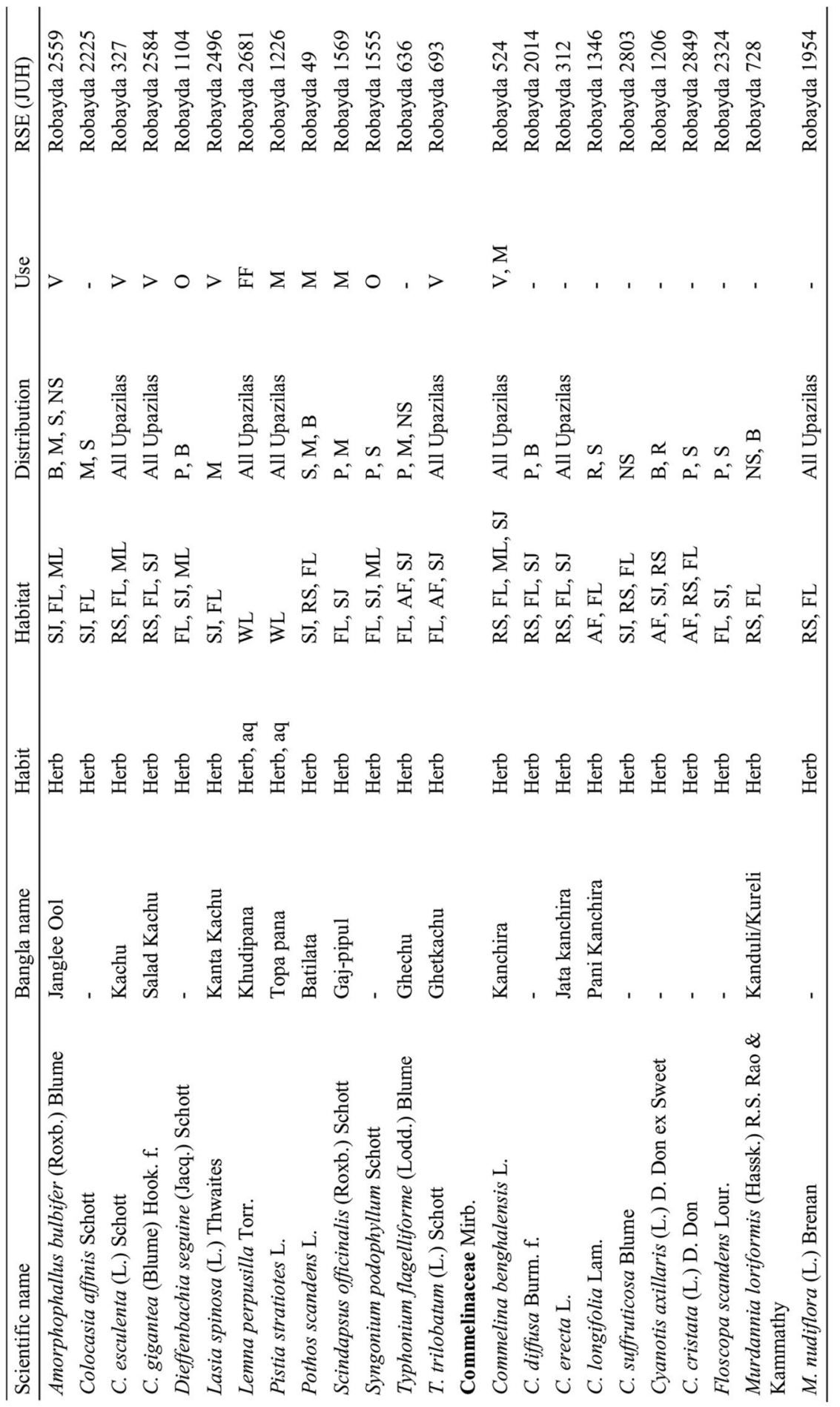




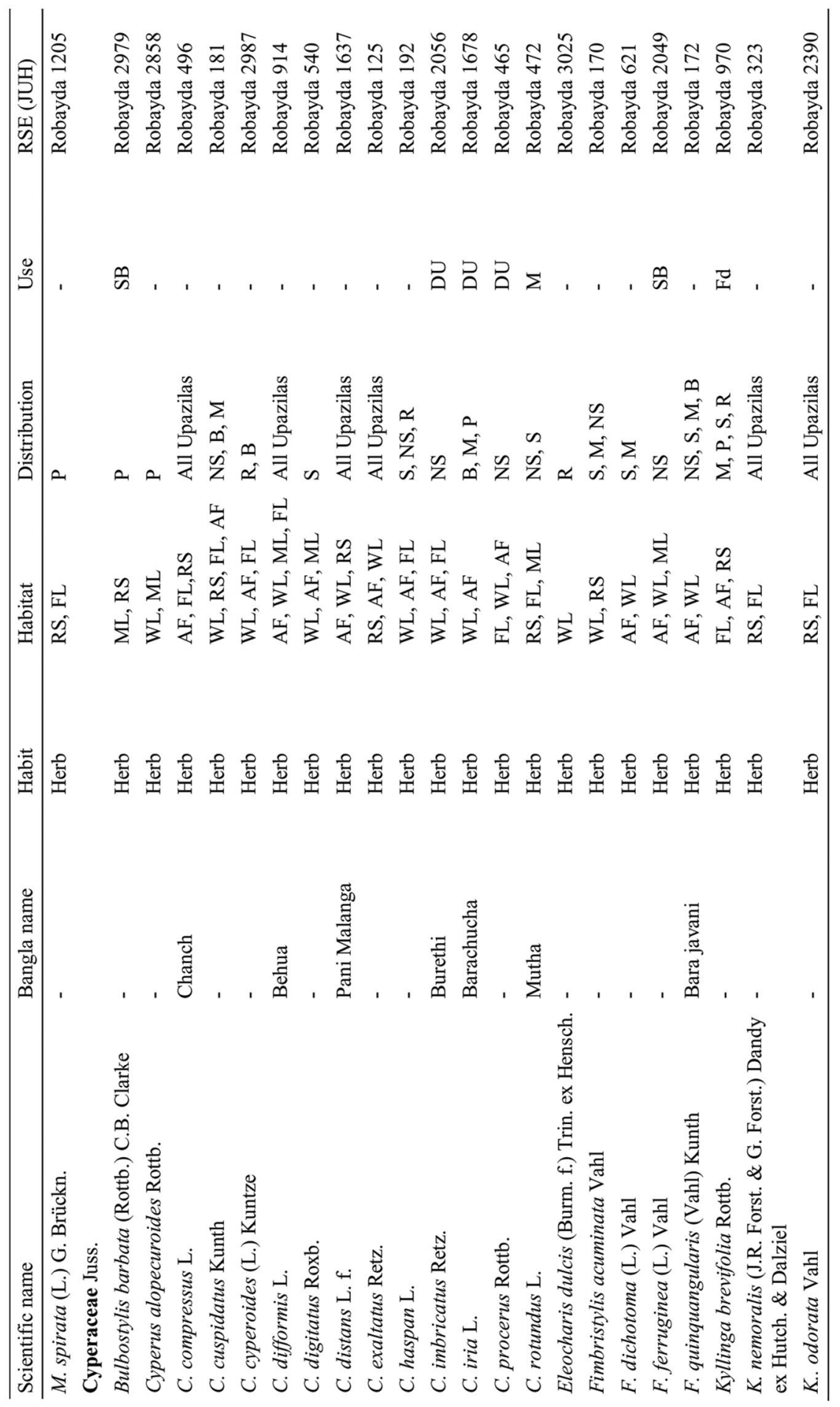




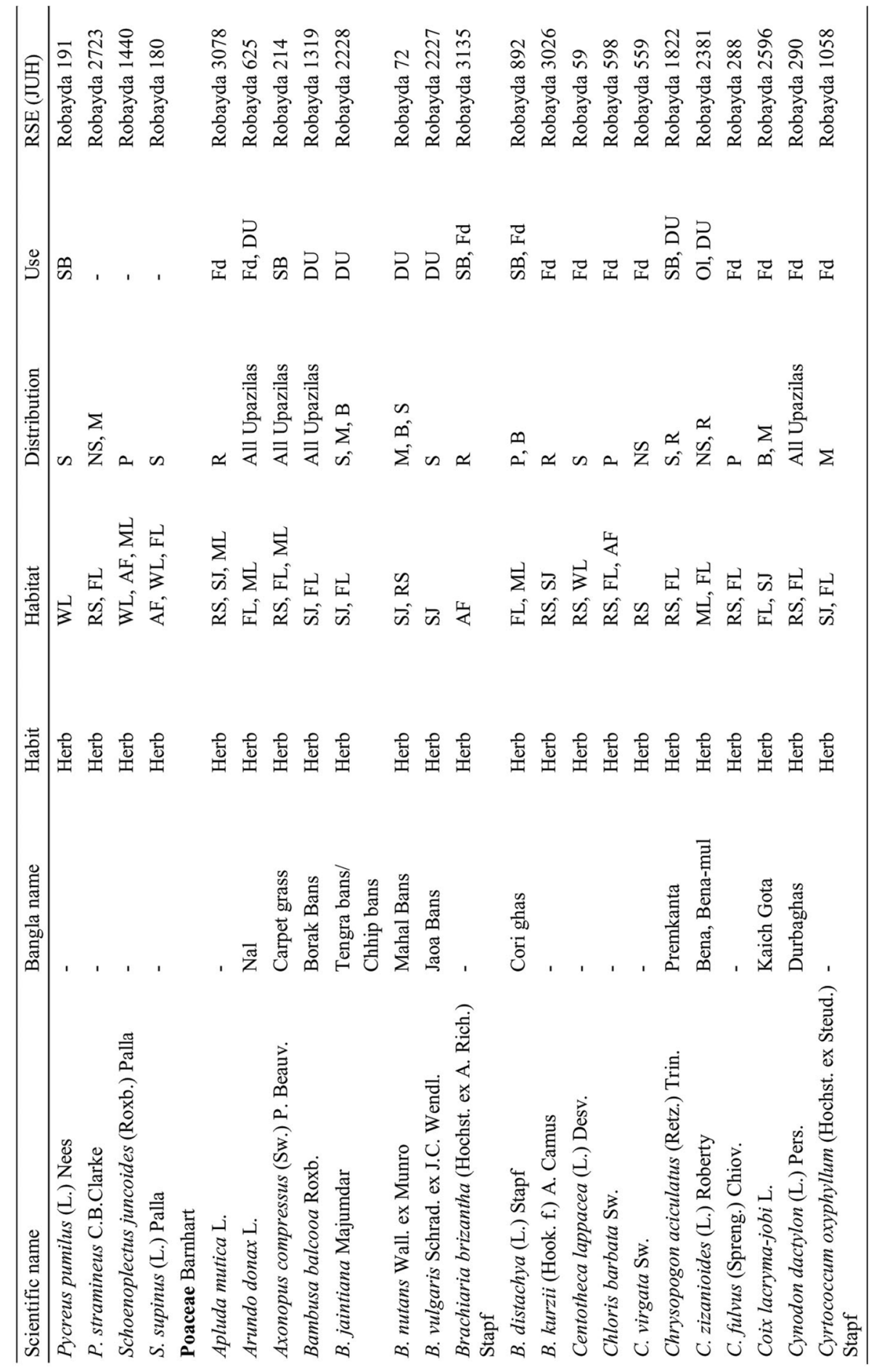




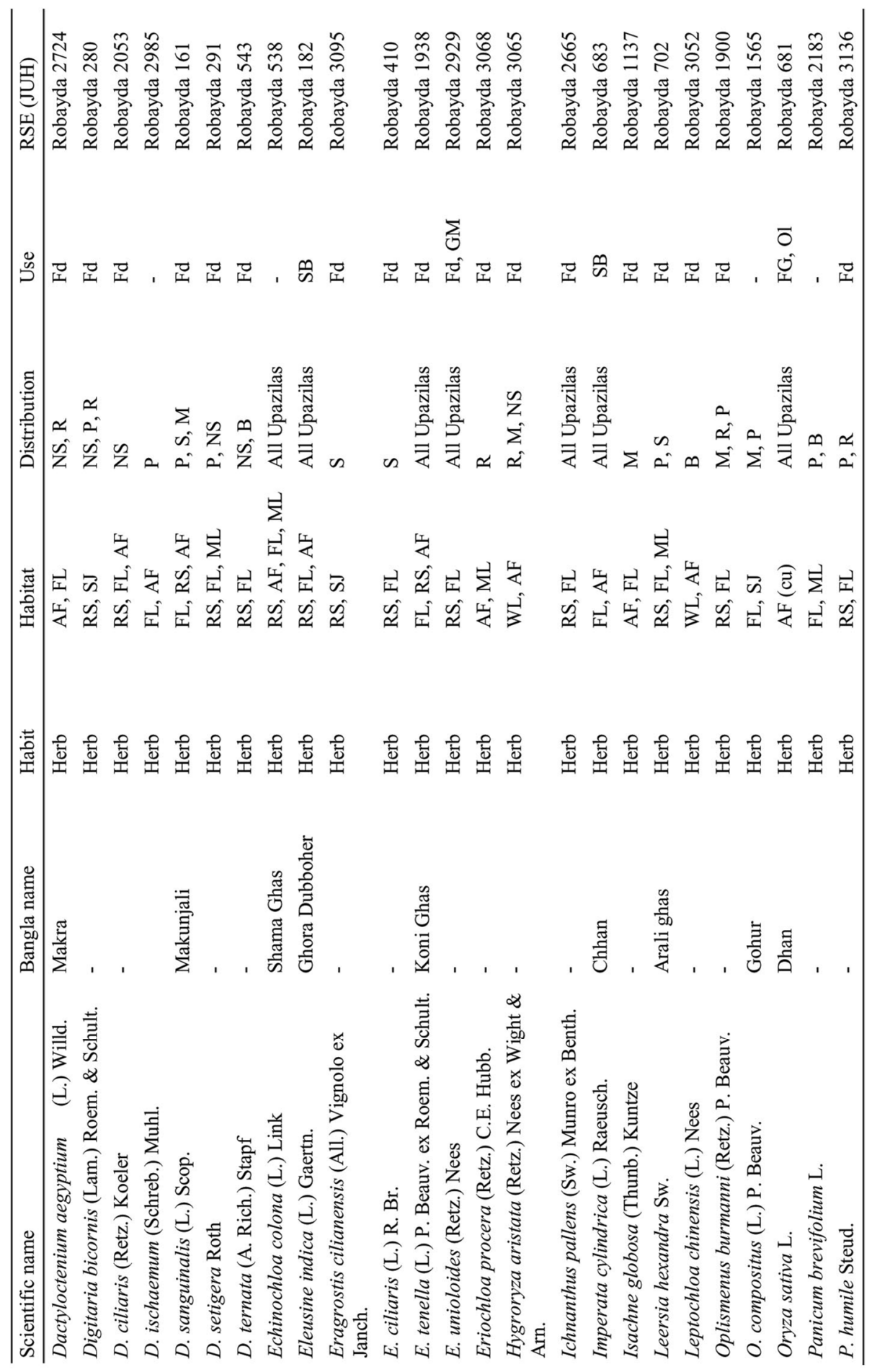




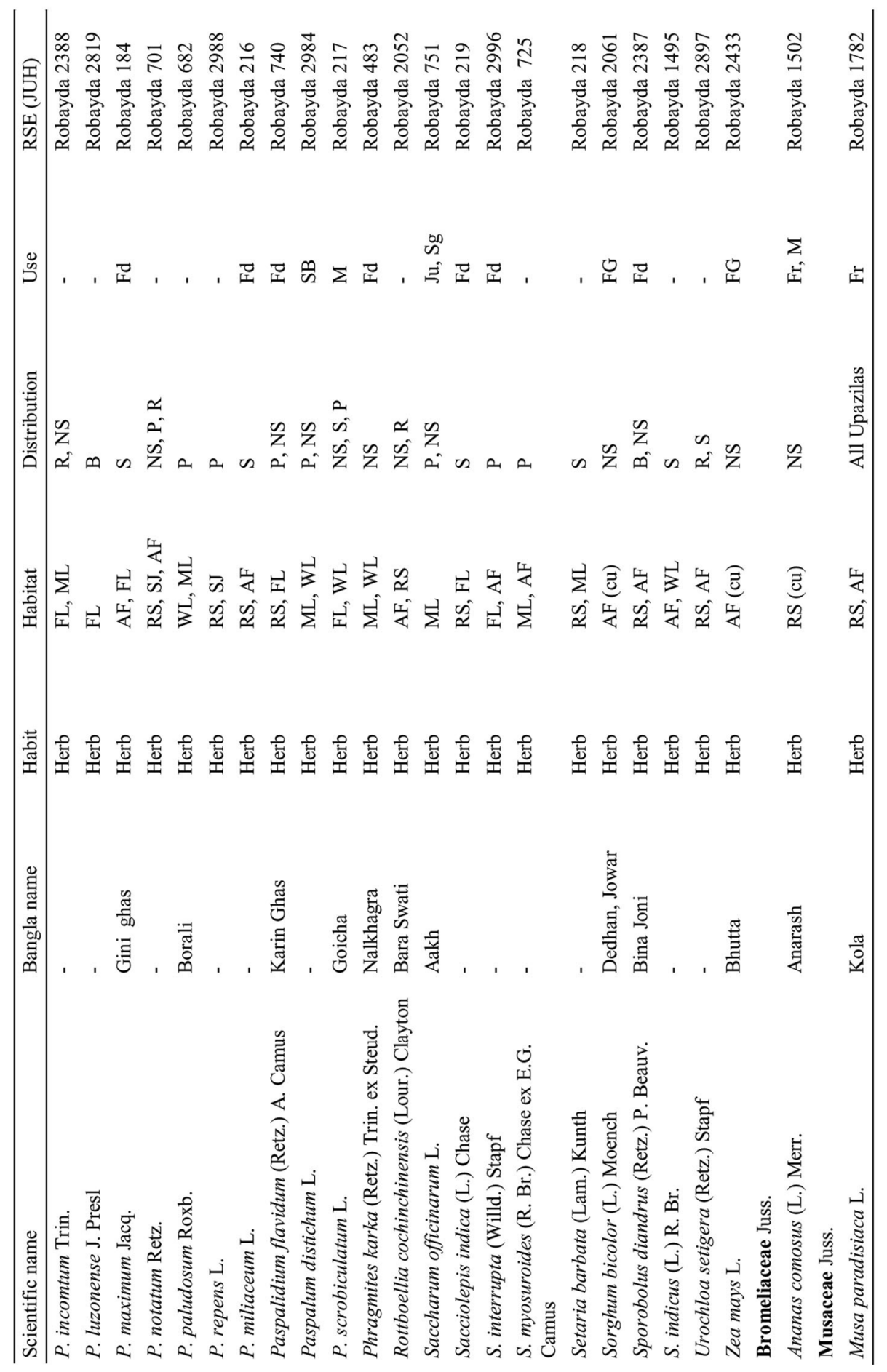




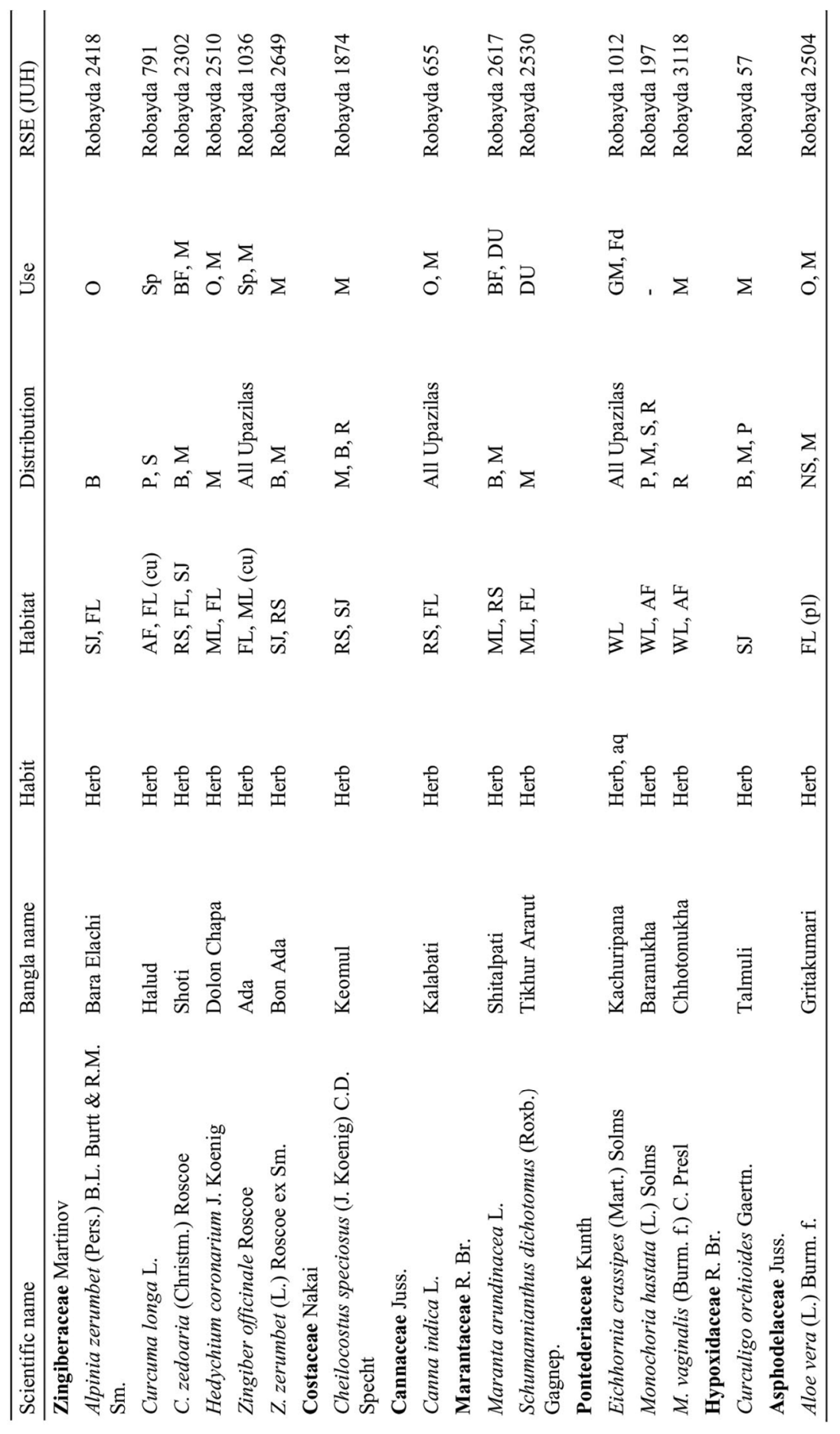




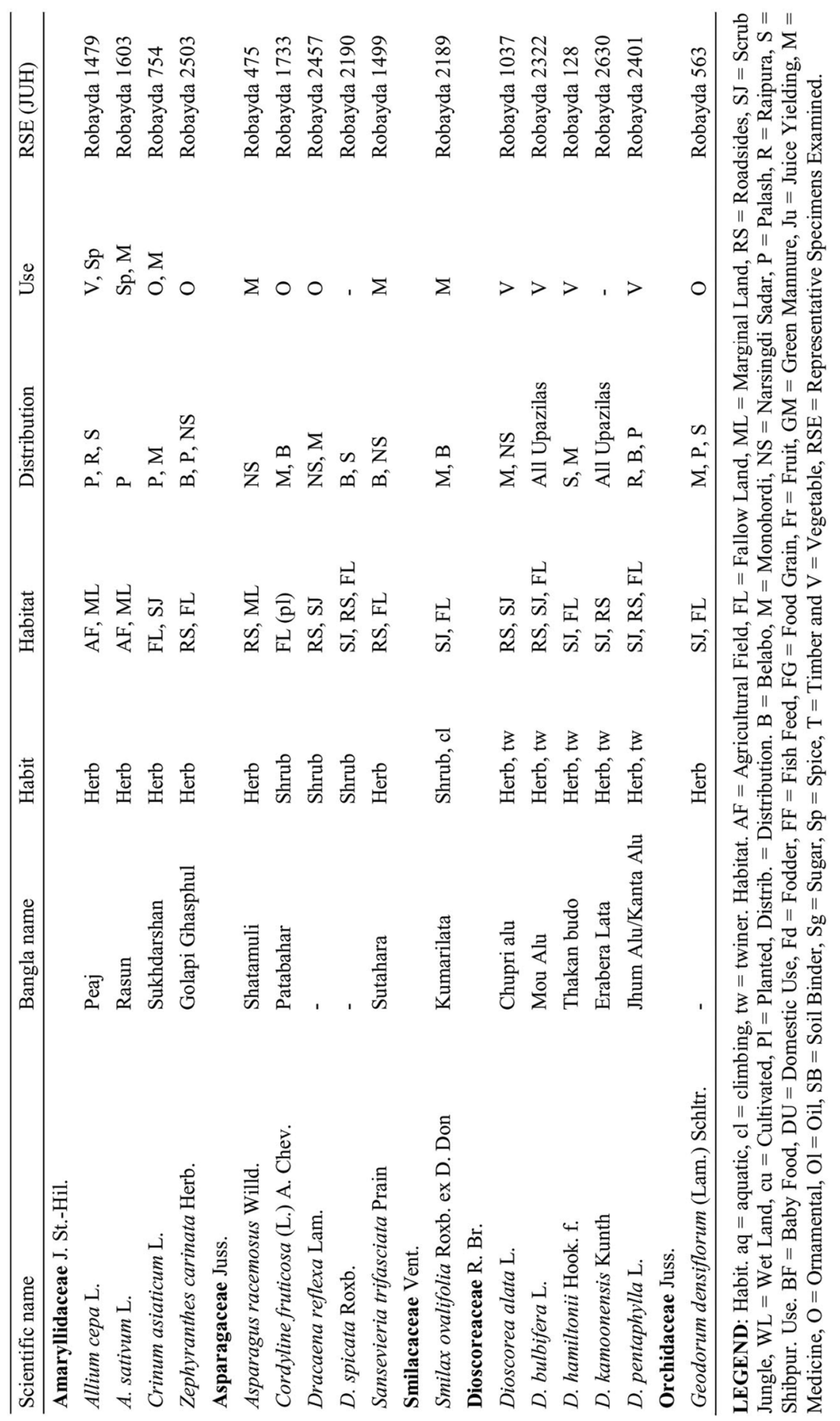


each. Poaceae with 66 species of 37 genera was appeared as the largest family in the study area, followed by Cyperaceae with 26 species of seven genera, Araceae with 16 species of 11 genera, Commelinaceae with 11 species of four genera and Arecaceae with 10 species of eight genera. Cyperus L. comprising 13 species was the best-represented monocot genus in this area, which was followed by Panicum L. with nine species, Digitaria Haller with six species, Commelina L. and Dioscorea L. with five species each. Rest of the families of the study area were consisted of two or three species each. Most of the species (152 species; 90.48\%) were herbs, and trees and shrubs comprised only eight species $(4.76 \%)$ each. The fallow lands harboring the highest number of species (102 species) comprised the most common type of habitat for the monocots in the study area that were followed by roadsides ( 80 species), scrub jungles (56 species), agricultural fields (55 species), marginal lands ( 42 species) and wetlands ( 36 species). Thus, these data indicate that Narsingdi district is still rich in monocotyledonous species and most of which are herbs and grow in fallow lands and roadsides.

The similarities between the habitats of the study area in species composition, measured by Jaccard coefficient (Fig. 1), shows that roadside and fallow land habitats share the highest similarity $(36.84 \%)$, whereas the roadsides and wetland the lowest $(4.5 \%)$. The similarity in species composition in between other pairs of habitats fluctuates from $4.5 \%$ (Roadside and Wetland) to $36.84 \%$ (Fallow land and Scrub jungle).

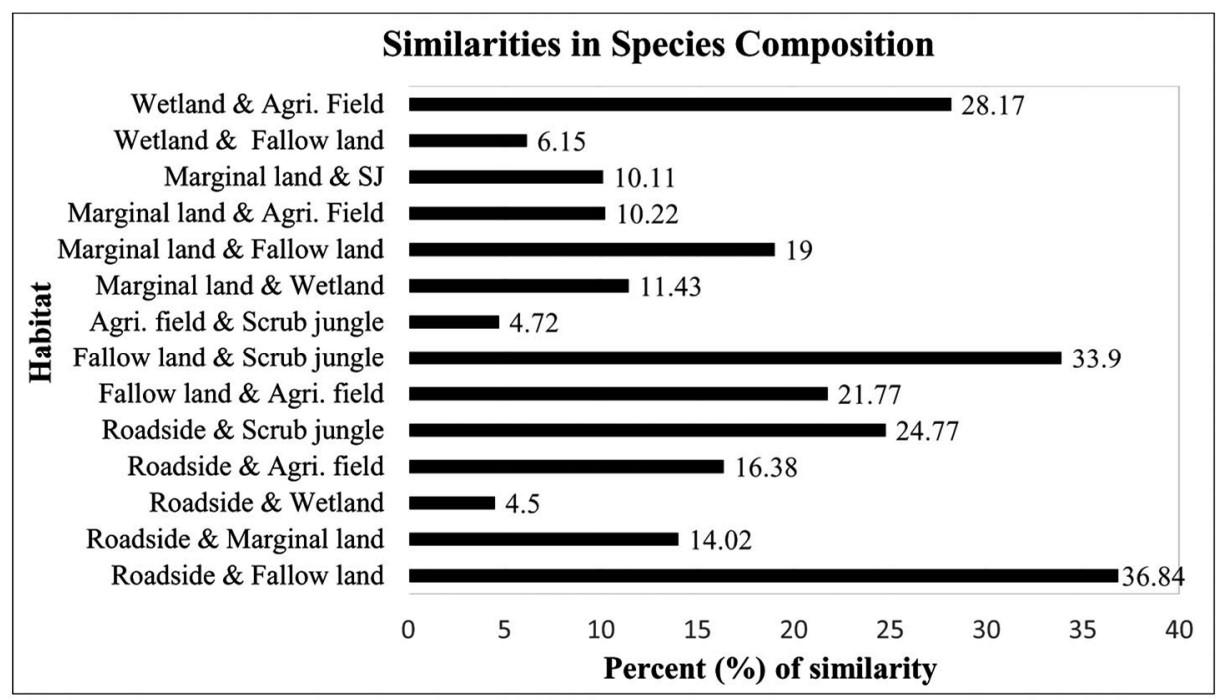

Fig. 1. Similarity in species composition in different habitats of Narsingdi district based on Jaccard coefficient (Jaccard, 1912).

In Narsingdi district, total 35 species, were commonly distributed in its all upazilas, 48 species in two upazilas, 27 species in three upazilas and only five species in four upazilas. 14 species were exclusively present in Palash, 12 in Shibpur, 11 in Narsingdi Sadar, seven in Raipura, six in Monohordi and only three in Belabo upazila. Monohordi upazila accommodated total 84 species, which was followed by Palash, Shibpur, Narsingdi Sadar, Belabo and Raipura upazilas harboring 81, 80, 79, 72 and 64 species, respectively. These data conclude that the monocot flora is richer in Palash, Belabo, Monohordi, and Shibpur upazilas, in comparison to that of Narsingdi Sadar and Raipura upazilas. However, if these species enumerations are considered in term of total 
land areas of these upazilas, then their sequence turns in to Palash, followed by Belabo, Monohordi, Shibpur, Narsingdi Sadar, and Raipura upazilas. According to the data from Jaccard coefficient (Fig. 2), all of the six upazilas of Narsingdi district shares $39.77 \%$ similarity in their species composition, which indicates that the species composition in these upazilas are more different rather than similar. However, if the similarity is compared in between any pair of the upazilas only, it fluctuates remarkably, from $6.45 \%$ (in Belabo and Raipura upazilas) to $32.31 \%$ (in Monohordi and Belabo upazilas).

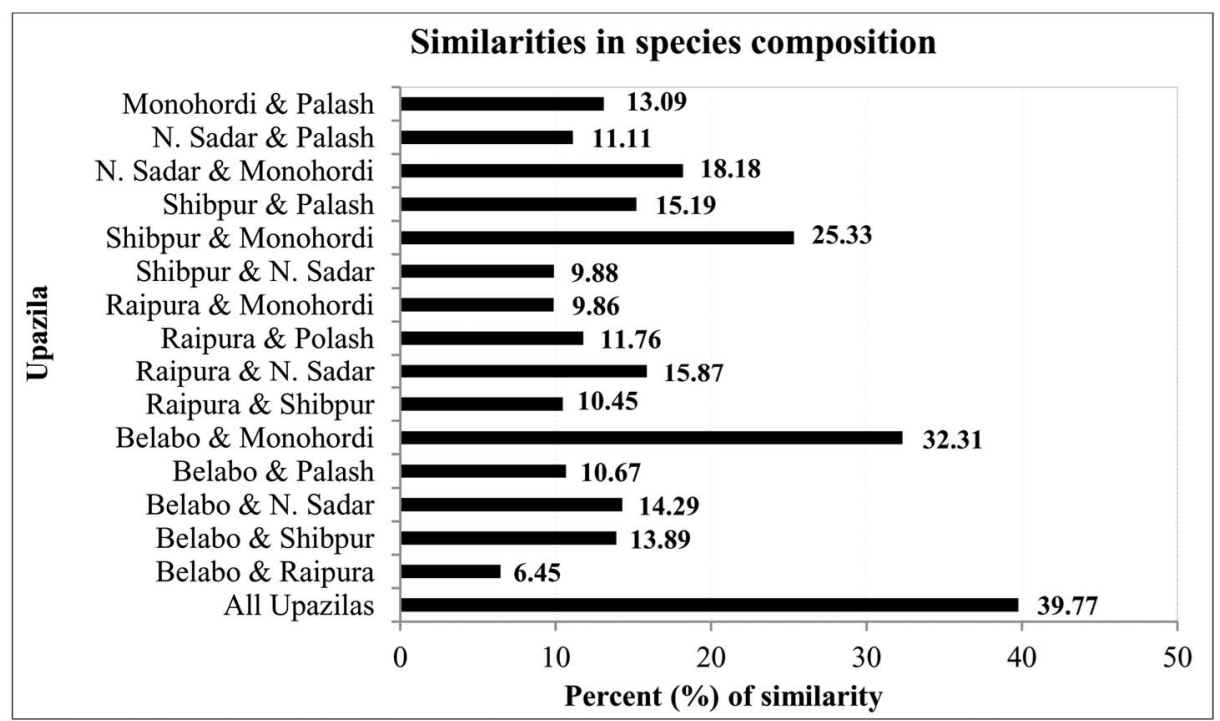

Fig. 2. Similarity in species composition in the upazilas of Narsingdi district based on Jaccard coefficient (Jaccard, 1912).

The enumeration of monocotyledonous species from the upazilas of Narsingdi district seems higher than that from some upazilas of few other districts reported by the previous studies (Islam et al., 2009; Rahman et al., 2012; Rahman et al., 2013; Sarker et al., 2013; Sajib et al., 2014; Mahmudah et al., 2017; Rahman et al., 2019). Considering the size of the study area, the monocotyledonous flora of whole Narsingdi district appears richer in comparison to those of Patuakhali district, Swandip Island and Rajshahi district, as reported by Sultana (2012), Sajib et al. (2015) and Rahman (2013), respectively, or even to that of mangrove forests (Rahman et al., 2015). Whereas, the monocotyledons of this district documented by this study is relatively poorer than those of few forest areas, viz. Sitapahar Reserve Forest (Uddin et al., 1998; Rashid and Chowdhury, 2013), Satchari National Park (Arefin et al., 2011), and Rajkandi Reserve Forest (Haque et al., 2018). The total number of monocot species (168) recorded from Narsingdi district is $17 \%$ of the total 988 species and that of monocot families (23) is $56.10 \%$ of the total 41 families reported for Bangladesh by Siddiqui et al. (2007) and Ahmed et al. (2008). It indicates that this floristic element of the study area is not negligible, though these proportions will be lower if the flora of Bangladesh is explored completely.

Most of the monocot species (117 species) recorded from the study area are economically useful. Majority of these species are useful as fodder (39 species) and medicinal (22 species), followed by domestic purpose (14 species), vegetable (13 species), ornamental (12 species), soil binding (nine species), spice (five species), oil yielding (four species), timber, fruit and food grain 
(three species each), and juice yielding, green manure, baby food and fish feed (two species each). Among these species, 24 can be useful in two to three categories. These data show that the monocot species of the study area can notably contribute in socio-economic purposes and favor sustainable development in the region.

The study area harbored many aquatic habitats of different categories (ponds, beels, jheels, low lands, rivers), which appeared suitable for some common monocot species (Eichhornia crassipes, Sagittaria guayanensis, Ottelia alismoides, Pistia stratiotes, Lemna perpusilla, Hygroryza aristata, Phragmites karka) and most of them flourished there vigorously. Some species (Axonopus compressus, Cynodon dactylon, Commelina benghalensis, Colocasia esculenta, Murdania nudiflora, Eleusine indica, Bambusa balcooa, Bambusa nutans, Imperata cylindrica, Curcuma zedoaria, Eragrostis unioloides, Echinochloa colona) were commonly distributed among the upazilas of the study area with normal natural regeneration. In contrast, Geodorum densiflorum, Curculigo orchioides, Phoenix acaulis, Bulbostylis barbata, Apluda mutica, and Lasia spinosa were occasionally found in this area and assumed to be declining because of their poor regeneration.

The major functional threats to the flora of the study area identified during this study are (1) vegetation clearing, industrialization, unnecessary firing, unplanned agricultural extension, over exploitation of natural resources through multifarious human interferences; (2) habitat fragmentation and depletion as the consequence of various anthropogenic activities and few natural events; (3) soil erosion due to clearing of vegetation cover, heavy rainfall and flood; (4) invasion of some exotic species, viz. Acacia auriculiformis A. Cunn. ex Benth., Chromolaena odorata (L.) R.M. King \& H. Rob., Eichhornia crassipes, Eucalyptus camaldulensis Dehnh., Mikania cordata (Burm. f.) B.L. Rob. and Parthenium hysterophorus L; (5)

poor regeneration in some species (Geodorum densiflorum, Curculigo orchioides, Phoenix aculis); (6) lack of awareness in the local people about the importance and conservation of plant diversity; and (7) lack of proper management programs in favor of natural regeneration and conservation of plant diversity. Considering these facts, this study suggests to conduct adequate inventories, monitoring and research programs on the flora and plant diversity of this district for knowing and improving their status and to implement appropriate conservation measures and management programs in favor of the depleting plant genetic resources of this area in order to contribute for sustainable development there.

This study provides important taxonomic data on the monocotyledonous species growing in Narsingdi district naturally. These information might be useful as the guiding database to track the trend of changes in species composition, diversity and vegetation of this plant group in course of time due to natural and anthropogenic stresses, contribute in studying animal diversity dependent on monocotyledonous species directly or indirectly, in undertaking appropriate biodiversity conservation initiatives and plant resource-based socioeconomic development and help in monitoring and estimating the impacts of climate change in this area.

\section{Acknowledgements}

The authors gratefully acknowledge the University Grants Commission of Bangladesh for awarding the PhD Fellowship to the first author for conducting her research including this study. They are grateful to the authority of Bangladesh National Herbarium (DACB) for allowing access to their libraries and relevant herbarium materials. The authors are also thankful to the Reviewers of the Journal for their critical review of the manuscript. 


\section{References}

Ahmed, Z.U., Hassan, M.A., Begum, Z.N.T., Khondker, M., Kabir, S.M.H., Ahmed, M., Ahmed, A.T.A., Rahman, A.K.A. and Haque, E.U. (Eds). 2008. Encyclopedia of Flora and Fauna of Bangladesh, Vol. 12, Asiatic Society of Bangladesh, Dhaka.

Angiosperm Phylogeny Group. 2016. An update of the Angiosperm Phylogeny Group classification for the orders and families of flowering plants: APG IV", Botanical Journal of the Linnean Society 181(1): 1-20. DOI:10.1111/boj.12385.

Arefin, M.K., Rahman, M.M., Uddin, M.Z. and Hassan, M.A. 2011. Angiosperm flora of Satchari National Park, Habiganj, Bangladesh. Bangladesh J. Plant Taxon. 18(2): 117-140.

BBS (Bangladesh Bureau of Statistics) 2011. Monthly Statistical Bulletin. Statistics Division, Ministry of Planning, Government of the People's Republic of Bangladesh.

Bridson, D.M. and Forman, F. 1989. In: Bridson, D.M. and Forman, F. (Eds). The Herbarium Handbook. Royal Botanic Gardens, Kew, pp. 214.

Cronquist, A. 1981. An integrated system of classification of flowering plants. Columbia University Press, New York, pp. 1-1262.

Ghani, A. 1998. Medicinal Plants of Bangladesh with Chemical Constituents and Uses. Asiatic Society of Bangladesh, pp. 1-467.

Haque, A.K.M.K., Khan, S.A., Uddin, S.N. and Shetu, S.S. 2018. An annotated checklist of the Angiospermic flora of Rajkandi Reserve Forest of Moulvibazar, Bangladesh. Bangladesh J. Plant Taxon. 2525(2): 187-207.

Hooker, J.D. 1872-1897. The Flora of British India, Vols. 1-7. L. Reeve \& Co., Ashford, Kent, UK.

Huq, A.M. 1986. Plant Names of Bangladesh. Bangladesh National Herbarium, BARC, Dhaka, Bangladesh, pp. 1-289.

IPNI 2018. International Plant Names Index. Published on the Internet http://www.ipni.org, The Royal Botanic Gardens, Kew, Harvard University Herbaria \& Libraries and Australian National Botanic Gardens. Accessed on16 September 2018.

Islam, M.R., Uddin, M.Z. and Hassan, M.A. 2009. An Assessment of the Angiospermic Flora of Ramgarh Upazila of Khagrachhari District, Bangladesh. Bangladesh J. Plant Taxon. 1616(2): 115-140.

Jaccard, P. 1912. The distribution of the flora of the alpine zone. New Phytologist 11: 37-50.

Jørgensen, P.M., Nee, M.H. and Beck, S.G. (Eds). 2014. Cat. Pl. Vasc. Bolivia, Monogr. Syst. Bot. Missouri Bot. Gard. 127(1-2): i-viii, 1-1744. Missouri Botanical Garden Press, St. Louis.

Khanam, R., Khan, S.A. and Rahim, A. 2020. Angiosperms in Narsingdi district of Bangladesh: Class Magnoliopsida. Bangladesh J. Plant Taxon. 27(1): 153-171.

Madagascar Catalogue, 2020. Catalogue of the Plants of Madagascar. Missouri Botanical Garden, St. Louis, U.S.A. [http://www.tropicos.org/Project/Madagascar. Accessed on 20 August 2020.

Mahmudah, Z., Islam, M.M, Haque, T. and Uddin, M.Z. 2017. Taxonomic Enumeration of Angiosperm Flora of Sreenagar Upazila, Munshiganj, Dhaka, Bangladesh. J. Asiat. Soc. Bangladesh, Sci. 43(2): 161-172.

Nasir, E. and Ali, S.I. (Eds). 1980-2005. Flora of Pakistan, Vols. 1-209. University of Karachi, Karachi, Pakistan.

Prain, D. 1903. Bengal Plants, Vols. 1 and 2. Reprint 1963. Botanical Survey of India, Calcutta.

Rahman, A.H.M.M. 2013. Angiospermic Flora of Rajshahi District, Bangladesh. American Journal of Life Sciences 11(3): 105-112.

Rahman, M.O., Begum, M. and Ullah, M.W. 2013. Angiosperm Flora of Sadar Upazila of Munshiganj District, Bangladesh. Bangladesh J. Plant Taxon. 20(2): 213-231.

Rahman, M.O. and Hassan, M.A. 1995. Angiospermic flora of Bhawal National Park, Gazipur (Bangladesh). Bangladesh J. Plant Taxon. 2(1\&2): 47-80.

Rahman, M.O., Antara, R.T., Begum, M. and Hassan, M.A. 2012. Floristic diversity of Dhamrai upazila of Dhaka with emphasis on medicinal plants. Bangladesh J. Bot. 41(1): 71-85. 
Rahman, M.O., Sayma, N.J. and Begum, M. 2019. Angiospermic flora of Gafargaon upazila of Mymensingh district focusing on medicinally important species. Bangladesh J. Plant Taxon. 26(2): 269-283.

Rahman, M.S., Hossain, M.G., Khan, S.A. and Uddin, S.N. 2015. An Annotated Checklist of the Vascular Plants of Sundarban Mangrove forest of Bangladesh. Bangladesh J. Plant Taxon. 22(1): 17-41.

Rashid, M.H.U. and Chowdhury, M.A.I. 2013. Additions to the Angiosperm Flora in the Sitapahar Reserve Forest of Kaptai, Rangamati, Bangladesh. Bangladesh J. Plant Taxon. 20(2): 255-257.

Schatz, G. E., Andriambololonera, S., Lowry II, P.P., Phillipson, P.B., Rabarimanarivo, M., Raharilala, J.I., Rajaonary, F.A., Rakotonirina, N., Ramananjanahary, R.H., Ramandimbisoa, B., Randrianasolo, A., Ravololomanana, N., Taylor, C.M. and. Brinda, J.C. 2020. Catalogue of the Plants of Madagascar. Missouri Botanical Garden, St. Louis, U.S.A. [http://www.tropicos.org/Project/Madagascar. Accessed on 20 July 2020.

Sajib, N.H., Uddin, S.B. and Islam, M.M. 2014. Angiospermic Plant Diversity of Subarnachar Upazila in Noakhali, Bangladesh. J. Asiat. Soc. Bangladesh, Sci. 40(1):39-60.

Sajib, N.H., Uddin, S.B. and Pasha, M.K. 2015. Angiospermic Plant Diversity of Swandip Island Chittagong, Bangladesh. J. Asiat. Soc. Bangladesh, Sci. 41(2): 133-153.

Sarker, K., Islam, M.R., Uddin, M.Z., and Hassan, M.A. 2013. Angiosperm Flora of Manikgonj Sadar Upazila, Bangladesh. J. Asiat. Soc. Bangladesh, Sci. 39(2): 147-166.

Shetu, S.S., Khan, S.A. and Uddin, S.N. 2018. Checklist of Angiosperms extant in Mirpur area of Dhaka City, Jahangirnagar University J. Biol. Sci. 7(2): 47-64.

Siddiqui, K.U., Islam, M.A., Ahmed, Z.U., Begum, Z.N.T., Hassan, M.A., Khondker, M., Rahman, M.M., Kabir, S.M.H., Ahmed, A.T.A., Rahman, A.K.A. and Haque, E.U. (Eds). 2007. Encyclopedia of Flora and Fauna of Bangladesh, Vol. 11. Asiatic Society of Bangladesh, Dhaka, Bangladesh.

Singh, H.B. and Subramaniam, B. 2008. Field Manual on Herbarium Techniques. National Institute of Science Communication and Information Resources, pp. 1-297.

Sultana, M. 2012. Taxonomic and ethnobatanical studies on the angiospermic flora of Patuakhali district In Bangladesh. Ph.D. Thesis (Unpublished). Department of Botany, University of Dhaka.

The Plant List. 2013. The Plant List, a working list of all plant species. Version $1.1<\mathrm{http}: / / \mathrm{www}$. theplantlist.org/>. Accessed on 01 January 2020.

TROPICOS 2017. Tropicos.org. Missouri Botanical Garden, Saint Louis, Missouri, USA. WWW.tropicos.org. Accessed on 25 August 2020.

Uddin, S.N., Khan, M.S., Hassan, M.A. and Alam, M.K. 1998. An annotated checklist of angiospermic flora of Sitapahar at Kaptai in Bangladesh. Bangladesh J. Plant Taxon. 5(1): 13-46.

Van Valkenburg, J.L.C.H. and Bunyapraphatsara. N. (Eds). 2002. Plant Resources of South-East Asia, No. 12(2). Medicinal and Poisonous Plants 2. Prosea Foundation, Bogor, Indonesia, pp. 1-782.

Wu, Z.Y. and Raven, P.H. (Eds). 2000. Flora of China, Vol. 24. Missouri Botanical Garden Press, St. Louis, USA.

Wu, Z.Y., Raven, P.H. and Hong, D.Y. (Eds). 2006-2010. Flora of China, Vols. 22, 23 and 25. Missouri Botanical Garden Press, St. Louis. USA.

Zuloaga, F.O., Morrone, O., Belgrano, M.J., Marticorena, C. and Marchesi, E. (Eds). 2008. Catálogo de las plantas vasculares del Cono Sur. Monogr. Syst. Bot. Missouri Bot. Gard. 107(1-3): i-xcvi, 1-3348. 